http://dx.doi.org/10.18232/alhe.1025

Artículos

\title{
El cooperativismo caficultor en Colombia: el caso de la Cooperativa de Caficultores de Andes en el Departamento de Antioquia, 1927-2015
}

\section{Coffee growers' cooperatives in Colombia: The case of the Andes Cooperative in the Department of Antioquia, 1927-2015}

Olga L. Arboleda ${ }^{1, *}$ * (D) 0000-0002-1436-904X

Hernando E. Zabala ${ }^{1}$ (DD 0000-0001-8725-3569

Eduardo N. Cueto ${ }^{2}$ (iD 0000-0002-2125-6828

${ }^{1}$ Universidad Católica Luis Amigó, Medellín, Colombia.

${ }^{2}$ Universidad Santo Tomás, Medellín, Colombia.

* Correspondencia: olga.arboledaal@amigo.edu.co

Resumen. El artículo expone el acontecer histórico del cooperativismo caficultor en Colombia, entre 1927 y 2015, teniendo como hito la creación de la Federación Nacional de Cafeteros y haciendo énfasis en un caso representativo: la Cooperativa de Caficultores de Andes -Cooperandes-, en el departamento de Antioquia. Busca identificar el significado de la relación entre la Federación como representante del gremio cafetero y las cooperativas, y el aporte de estas al mejoramiento de condiciones de vida de los asociados y sus familias. La hipótesis se orienta a mostrar que este tipo de organizaciones no sólo han sido un aliado estratégico de

CÓMO CITAR: Arboleda, O. L, Zabala, H. E. y Cueto, E. N. (2020). El cooperativismo caficultor en Colombia: el caso de la Cooperativa de Caficultores de Andes en el Departamento de Antioquia, 1927-2015. América Latina en la Historia Económica, 27(1), e1025. DOI: 10.18232/alhe.1025 
la institucionalidad cafetera, sino que también han contribuido al desarrollo local de las comunidades que las albergan. La metodología se enfoca desde la investigación cualitativa, el método de presentación de caso y la técnica documental.

Palabras clave: cooperativismo de producción; desarrollo local; economía solidaria; historia regional.

Abstract. The article exposes the historical events of the coffee cooperative in Colombia, between 1927 and 2015, taking as a milestone the creation of the National Federation of Coffee Growers and emphasizing a representative case: The Cooperativa de Caficultores of Andes -Cooperandes-, in the Antioquia's Department. It seeks to identify the meaning of the relationship between the Federation as a representative of the coffee guild and the cooperatives, and the contribution of these to the improvement of the living conditions of the members and their families. The hypothesis is oriented to show that this type of organizations have not only been a strategic ally of the coffee institutionality, but they have also contributed to the local development of the communities that house them. The methodology focuses on qualitative research, the case presentation method and the documentary technique.

Key words: production cooperativism; local development; solidarity economy; regional history.

JEL: J54; R1; D6; N96.

Recibido: 14 de septiembre de 2018.

Aceptado: 30 de noviembre de 2018.

Publicado: 1 de octubre de 2018.

\section{INTRODUCGIÓN}

Colombia tiene una inmensa tradición agrícola en el área de la caficultura, destacándose algunas regiones ubicadas en las estribaciones montañosas que circundan el río Cauca: entre ellas la región del suroeste antioqueño a la cual pertenece el municipio de Andes.

En términos de la economía, el gremio cafetero ha señalado para los últimos años que la actividad ha creado aproximadamente 785000 empleos directos a $26 \%$ de la totalidad del sector agrícola; ha arrojado cosechas por valor de 5.2 billones de pesos colombianos, lo cual se ha redistribuido como ingreso entre las más de 550000 familias que habitan en 595 municipios donde se cultiva el grano; además el café produce 33 \% de las exportaciones del sector agropecuario de Colombia, con lo cual su contribución a las exportaciones, alcanza $4.4 \%$ (Arranca la cosecha, 2015). En 2015 el valor de las exportaciones del grano alcanzó 2787 millones de dólares, en tanto que la producción de café en Colombia alcanzó 14200000 sacos y el valor de la cosecha anual fue de 6.2 billones de pesos (Federación Nacional de Cafeteros 2015, pp. 8-10).

En cuanto al estimativo del valor del ahorro cafetero histórico anual se tiene que desde el fortalecimiento generado en las finanzas del Fondo Nacional del Café a través de la puesta en marcha del acuerdo para la prosperidad cafetera, se da el aumento de la capacidad de ahorro en épocas de holgura y de precios altos, lo cual se evidencia, por ejemplo, para el año 2011 se destina un rubro de 300000 millones de pesos para garantizar el impulso de los programas de renovación, investigación, reforestación y asistencia técnica, así como recursos por 25000 millones destinados a la ejecución de programas de vivienda de interés social rural en la zona cafetera y aunado a esto, se incrementa de manera progresiva en los últimos años (2015) un valor aproximado del ahorro cafetero en 801000 millones de pesos anuales (Federación Nacional de Cafeteros 2010, p. 46). 
Otros de los aspectos característicos del sector, son la condición de fragmentación en la posesión de tierras, la economía de subsistencia, los niveles bajos de satisfacción de necesidades básicas y el bajo nivel educativo, aspectos que son frecuentes en el agro latinoamericano y que hacen que las familias dedicadas al cultivo sean muy susceptibles a los fenómenos económicos del entorno. Ante esta realidad, una de las formas para hacerle frente a la problemática y conseguir beneficios para todos, es estar unidos en un gremio fuerte y con sólidas instituciones.

Específicamente sobre la posesión de tierras fragmentadas para el cultivo de café, es conveniente señalar que ello tiene significativa relación con la forma como se asignó la tierra después de la independencia mediante la adjudicación de baldíos:

La introducción del café, un cultivo que se adapta a las empresas familiares en pequeña escala, ha contribuido de manera importante a la formación de esta sociedad de propietarios en las tierras volcánicas del sur de Antioquia, Caldas y Tolima [...].

A las poblaciones antioqueñas fundadas entre 1835 y 1914, se les otorgaron por lo menos 26 concesiones de baldíos (de doce mil hectáreas en promedio cada una), en desarrollo de la política tendiente a estimular la colonización de las tierras ocupadas. Estas nuevas colonias [...] eran asociaciones agrarias, unidas fraternal y sólidamente, entre las cuales se había desarrollado el cooperativismo en el desmonte, la siembra y la cosecha, y un alto sentido de responsabilidad comunal Parsons (Parsons, 1997, pp. 154-155).

Según Parsons, las siguientes poblaciones antioqueñas, fueron objeto de concesión de fanegadas de tierras baldías: Concordía, 12 000; Amalfi, 9 000; Turbo, 8 000; Ituango, 9 000; Murindó 12000 y Nare 9 000.En este aspecto es importante tener en cuenta que en Colombia una fanegada equivale a 0.64 hectáreas de tierra.

Las parcelas distribuidas comprendían entre 60 y 150 fanegadas por familia, de acuerdo con el número de miembros y la calidad de las tierras y la norma para realizar la concesión comprendía el siguiente proceso: "El consejo nombrado tenía la responsabilidad de preparar la lista de las personas elegibles, para lo cual designaba [...] una junta de tres individuos que llevaban a cabo las adjudicaciones" (Parsons, 1997, p. 155).

De acuerdo con lo anterior, en este trabajo, se presenta una recuperación histórica, sistemática y reflexiva de aspectos relacionados con el cooperativismo caficultor en Colombia durante el periodo comprendido entre los años 1927 y 2015 y expone la experiencia de una de las organizaciones más representativas en este sector como lo es la Cooperativa de Caficultores de Andes (en adelante, Cooperandes), ubicada en el municipio del mismo nombre, en el suroeste del departamento de Antioquia, Colombia.

El periodo definido para el desarrollo de la temática en mención, comprende los años entre 1927 y 2015, lo cual se justifica ya que, en el año de partida, 1927, aconteció en el orden de la historia económica de Colombia, la creación de la Federación Nacional de Cafeteros en el marco del Congreso Cafetero, realizado en el Club Campestre de Medellín, donde asistieron líderes de la región Antioqueña conocedores de las necesidades de los productores en esa y otras comarcas. El objetivo de la creación de la federación era representar a los caficultores en los ámbitos, nacional e internacional, velando por su seguridad y la de sus familias.

Este organismo gremial motivó y auspició, a partir de las décadas de 1950 y 1960, la creación de las cooperativas de caficultores en Colombia, proceso este que ha seguido acompañando hasta la actualidad, consiguiendo que el cooperativismo caficultor haya actuado durante todos estos años 
como un aliado estratégico de la institucionalidad cafetera y que, a su vez, el desarrollo institucional de la industria del café durante la segunda mitad del siglo xx y las décadas recorridas del xxI, se haya destinado significativamente al apoyo de actividades orientadas a promover el desarrollo de la población caficultora, a través de las cooperativas de caficultores. Sin embargo, algunos datos, se presentan más actualizados hasta 2018, por considerar que con ellos se aportan elementos que facilitan una mayor comprensión en el transcurrir histórico del tema interés del artículo.

El trabajo se delimita a 2015, debido a que los documentos fuente que manejan estadísticas del cooperativismo caficultor, como son los provenientes de la Federación Nacional de Cafeteros y la Superintendencia Nacional de la Economía Solidaria, tienen consolidados sus informes estadísticos a esta fecha.

La hipótesis orientadora del artículo plantea que la organización del caficultor bajo la forma del sistema cooperativo, auspiciado desde una forma gremial como lo es la Federación Nacional de Cafeteros de Colombia, se ha entendido desde sus comienzos como un mecanismo que ha resultado beneficioso para ambos sectores, el del gremio de cafeteros y el cooperativo adscrito a la economía solidaria, porque desde la articulación entre ambos - gremio y cooperativas-, no sólo se ha garantizado la comercialización del grano, sino también la sostenibilidad de la vida campesina, al contribuir al mejoramiento de unas condiciones de vida digna de esta población, lo cual da la posibilidad de hablar, a partir de la dinámica de estas organizaciones, de una "cultura cooperativa de tipo empresarial que impregna el accionar de los actores y el despliegue de las capacidades organizacionales" (Olivera, 2013, p. 230).

En este orden de ideas el artículo comprende tres capítulos: el primero de antecedentes o contextualización teórica que muestra la importancia del café en la economía colombiana, el segundo sobre características del cooperativismo caficultor en Colombia y en Antioquia y el tercero, con la descripción del caso particular de la cooperativa de Andes en términos de las trayectorias socio históricas que marcan su origen y proceso fundacional, los desarrollos socioeconómicos implementados en favor del mejoramiento de las condiciones de vida de los asociados y finalmente la estructura organizativa, en la que se expresa el modelo de gestión con la cual la organización trabaja y logra alcanzar su objeto social.

En el marco de la investigación, a la cual obedece este artículo, es necesario precisar que, desde la perspectiva de la investigación documental, se utilizan fuentes secundarias representadas en informes de la Federación Nacional de Cafeteros, de la Superintendencia de Economía Solidaria y de gestión de la Cooperandes. Igualmente se utiliza bibliografía de autores y trabajos de grados que analizan el surgimiento y desarrollo del cooperativismo caficultor en Colombia y en Antioquia.

Es necesario resaltar, que las fuentes primarias, sobre este tema son escasas y que la información estadística que se presenta no conserva una continuidad periódica para las primeras décadas de evolución del cooperativismo caficultor. En este sentido, en términos generales, los datos presentados por estas fuentes están puntualmente ubicados en los años 1972, 1983 y 1984. Estadísticas y análisis más continuos se presentan para el periodo 2000-2015. 


\section{CONTEXTUALIZACIÓN HISTORIOGRÁFICA}

\section{La importancia del café en la economía colombiana}

A través del tiempo y de la historia, la humanidad en todos sus procesos evolutivos y culturales ha tenido la necesidad de generar transacciones comerciales que le permitan ampliar el número de bienes de consumo y de esta forma mejorar las condiciones del bienestar, en este sentido, el café ha tenido relevancia en el marco de la economía de muchos países y, por ejemplo, pueblos de religión y cultura musulmana, particularmente los árabes, han tenido papel importante en el cultivo y consumo de dicho producto.

Dentro de un contexto histórico universal, puede decirse que para mediados del siglo xvII se da una reducción significativa del dominio de la producción del café en los mencionados pueblos musulmanes. Por ser un cultivo tropical, los holandeses y posteriormente los franceses y portugueses desarrollaron plantaciones en sus colonias de Asia, América y posteriormente África. Esta relación se mantuvo mientras las potencias europeas alcanzaban sus dominios de ultramar (Federación Nacional de Cafeteros de Colombia, 2010).

El café se convirtió en uno de los más importantes detonantes del desarrollo económico de muchos países latinoamericanos en los siglos XIx y xx, y para el caso colombiano existe una prelación, no sólo por su importancia en términos de generación de divisas, sino porque los ingresos derivados del producto y las necesidades de su procesamiento, facilitaron la creación de mercados internos que demandaron otro tipo de bienes y servicios. La producción de café no requería de costosos insumos importados y generaba anhelados ingresos por exportación para una economía frágil y con poca exposición al comercio internacional (Federación Nacional de Cafeteros de Colombia, 2010).

Según Ocampo (1994) el cultivo del café en Colombia se propagó entre 1732 y 1810 . De 1850 en adelante el cultivo se implementa desde Santander, Huila y Cundinamarca hacia otras regiones de Colombia, y entre 1874 y 1900 recibió un impulso con la inauguración del Ferrocarril de Antioquia (Palacios, 1979).

Conforme a la devaluación del peso colombiano, el valor del dólar creció al tiempo que las exportaciones del grano crecieron diez veces entre 1870 y 1915. A medida que se incrementa el cultivo, se necesitan más lugares de beneficios y una cadena de ocupaciones distintas a las agrícolas: el transporte, el mercadeo y la tarea industrial. Durante las dos primeras décadas del siglo xx, el cultivo y el comercio del café en Colombia registraron un increíble crecimiento, constituyéndose en el principal producto del sector agrario; de su exportación provenía más de $50 \%$ de las divisas en monedas extranjera (Palacios, 1979).

La inclinación a apreciar la producción cafetera como la más significativa para Colombia influyó positivamente en varios aspectos como la provisión de créditos, la enseñanza agrícola y el desarrollo de la infraestructura de transporte, tanto en los modos férreos y marítimos como el modo carretero, en favor de la agremiación de sus productores, lo cual llevó a la creación de la Federación Nacional de Cafeteros de Colombia en 1927. Dicha institución con su notable influencia y desarrollo, en la perspectiva del fomento de la producción, implementa un gravamen a la exportación del café según la Ley 76 de 1927, sobre protección y defensa del grano (Ospina, 1987, p. 390). 
La Ley 76 (Colombia. Congreso de la República, 1927, p. 1) crea una contribución sobre el café que se exporte de diez centavos por cada saco de $60 \mathrm{~kg}$ y señala que para que el poder ejecutivo pueda hacer efectivo este impuesto deberá celebrar previamente con la Federación Nacional de Cafeteros un contrato para la prestación de varios servicios a costa de la federación, relacionados con organizar y sostener una activa propaganda científica a favor del café colombiano, tomar las medidas necesarias para implantar en Colombia los mejores sistemas para el cultivo de la planta, para beneficio del fruto y para proteger tanto a los trabajadores como a las plantaciones contra el peligro de las enfermedades propias de las zonas y climas cafetero, y establecer por cuenta de la federación almacenes generales de depósito de acuerdo con la ley y con el gobierno, con el exclusivo objeto de que los que se interesan por la industria y comercio de café se beneficien con todas las ventajas de esa clase de instituciones.

De acuerdo con la Ley 76, la federación debe enviar comisiones de expertos a los distintos países productores y consumidores de café a estudiar los métodos de cultivo y beneficio, de venta, de propaganda y de financiación y, principalmente, a investigar las posibilidades de una mayor extensión en el cultivo y producción del grano que puede afectar el porvenir del mercado mundial del café. Igualmente, la federación debe fomentar el establecimiento de tostadoras, en el interior del país y en los centros de consumo importantes del extranjero y editar una revista u órgano de publicidad, para información del gremio; además, generar estadísticas del ramo en publicaciones para mantener informados a los interesados en este comercio, en lo relativo a cotizaciones en todos los mercados, a existencias en los distintos centros, a ventas efectuadas, a prospectos de producción mundial de café y a encauzar las corrientes de exportación de café hacia los distintos mercados europeos, americanos y demás centros mundiales que se juzgue conveniente, y en general, del desarrollo de un plan definitivo y práctico en beneficio de la industria cafetera colombiana (Colombia. Congreso de la República, 1927, p. 1).

Desde el transcurrir histórico, el café fue durante varias décadas un soporte material de la acumulación interna de capital, y estuvo estrechamente vinculado con los orígenes de la industria nacional y con el despliegue del mercado interno, es decir, fue fuente de financiamiento para el resto de la economía colombiana, además de vincularla con la economía internacional (Ocampo, 1994).

Sin embargo en la década del siglo xxi, el peso relativo de la caficultura dentro del conjunto de la economía colombiana fue perdiendo participación, por ejemplo, en el PIB del sector agropecuario pasó de representar cerca de $25 \%$ hacia finales de la década de 1970, a más o menos $6 \%$ durante los primeros diez años de la década del 2000; esto causado no sólo porque la producción no ha crecido y porque los precios internacionales han bajado, "sino también por el crecimiento muy significativo de otros sectores, en particular el minero energético, y de otros cultivos de tardío rendimiento, como la palma de aceite y los frutales, además de las flores y de la producción y comercialización externa de otros alimentos procesados" (Cano, Vallejo, y Tique, 2012, p. 9).

Igualmente, el cambio climático y fenómenos como el de la Niña han ejercido efectos negativos sobre la productividad de los cultivos, llevando a contemplar hacía el futuro "técnicas biotecnológicas de adaptación de los cultivos y, probablemente, una recomposición regional de la producción hacia zonas de mayor altura y tierras susceptibles de ser mecanizadas" (Cano et al., 2012, p. 10).

En cuanto al concepto de la mano de obra, el subsector del café absorbe $35 \%$ de la fuerza de trabajo del mercado agrícola, y el contexto se vuelve más crítico, toda vez que la industria nacional y los servicios no logran ocupar toda la fuerza de trabajo disponible (excedente de mano 
de obra), por lo cual este ejército industrial de reserva va a engrosar la economía informal (Cano et al., 2012), que de manera directa influye sobre el decrecimientos de la calidad de vida y por tanto en el desarrollo económico de Colombia.

Como puede observarse, en el recorrido histórico de la economía colombiana la industria del café ha sido motor de desarrollo que ha contribuido a diversificar de manera notable la actividad productiva nacional.

\section{El cooperativismo caficultor en Colombia y Antioquia}

Ante la necesidad de hacer viable, eficiente y competitiva la actividad caficultora colombiana, los productores del grano se reunieron en torno al Segundo Congreso Nacional Cafetero, en Medellín, capital del Departamento de Antioquia, en junio de 1927 y crean la Federación Nacional de Cafeteros de Colombia, la cual contó con el apoyo de la Sociedad de Agricultores de Colombia y de los gobiernos nacional y regional.

En el desarrollo de las funciones de la federación se perfila la iniciativa de fortalecer la comercialización y asegurar la garantía de compra del café, por lo cual se inicia un proceso ampliado de creación de las cooperativas de caficultores desde finales de la década de 1950 en los territorios de mayor densidad productiva.

Este proceso implicó la creación de una sección de cooperativas al interior de la federación y la realización de un conjunto de estudios socioeconómicos, cuya elaboración fue encomendada a Francisco Luis Jiménez Arcila, ideólogo del cooperativismo nacional y mundial y cuyas orientaciones serían clave para el proceso fundacional de las mencionadas cooperativas. Así, gran parte de la obra doctrinaria, sociológica y económica de Jiménez se ubica en la organización del movimiento cooperativo de caficultores, mediante la realización de estudios socioeconómicos en cada uno de los casos principales de formación de este tipo de entidades en los departamentos de Risaralda, Quindío, Antioquia, Caldas, Valle del Cauca, Tolima y Cundinamarca. De esta manera, el cooperativismo caficultor, auspiciado por la Federación de Caficultores de Colombia, encuentra en Jiménez su mayor promotor y realizador.

El objetivo general de la fundación de estas cooperativas estuvo orientado al mejoramiento de las precarias condiciones de vida de los cultivadores del grano, y este propósito conllevaba especificidades que tienen que ver con el aumento de la producción del grano, pero también con su calidad y mejoramiento de la tecnología, de las condiciones de transporte, de los beneficiaderos ${ }_{1}^{1}$ la diversificación de los cultivos. De manera importante, se proponía trabajar también en el fomento de condiciones de producción comunitarias y en la procura de condiciones para una vida más digna de los caficultores, en términos de vivienda, salud, educación y alimentación, al respecto Jiménez (2002) señala:

Cuando se fundó la primera, algunos productores fundadores propusieron que el apelativo fuera cafetera [...] Uno de nosotros manifestó que el verdadero fin de la cooperativa no era propiamente el cafetal y su producto, sino que la verdadera misión era la

\footnotetext{
${ }^{1}$ Estructura o espacio físico en el que se lleva a cabo el proceso por el cual se logra la transformación de café en cereza a café pergamino seco, mediante la separación de las partes del fruto y secado de los granos, con el fin de conservar su calidad física y sanitaria.
} 
defensa, la dignificación y la redención del dueño de la empresa, en un 80 por ciento parceleros y a causa de esa limitación, la producción era escasa por carencia de medios y recursos para la debida explotación. De ahí el calificativo de caficultores.

En las visitas que se hicieron a varias veredas de la región, se pudieron constatar las precarias condiciones de vida de las familias sin crédito, entonces, y por ello víctimas de los fonderos, sin asistencia médica, sin medios para educar a sus hijos, sin agua potable, sin beneficiaderos adecuados, sin sistema de transporte económicos, con una alimentación insuficiente, en una palabra, en extrema pobreza, las cooperativas tenían que salvar a los pequeños y por eso se proyectó la cooperativa de carácter integral (Jiménez, 2002, p. 109).

Precisamente en relación con el proyecto de fundar cooperativas integrales, la idea inicial en estos estudios incluía el mejoramiento social y económico de los productores y trabajadores cafeteros mediante dos estrategias: prestación de servicios en forma individual para los productores y sus familias y la organización de dichos servicios en unidades económicas, las cuales eran definidas como extensiones de tierra en escenarios de ruralidad según características aprobadas por el Comité Nacional de Cafeteros en acuerdo con los comités departamentales. En dichas unidades se implementarían servicios y beneficios para la población campesina, representados en escuelas rurales, centros de salud, centros de atención para niños, construcción de viviendas y beneficiaderos, entre otros. Sin embargo, esta idea no cobró forma y se procedió simplemente a la creación de cooperativas de caficultores en diferentes localidades de Colombia (Zabala y Arboleda, 2007).

De esta manera, la primera de las cooperativas de caficultores creada en Colombia, fue la de Pereira, que, fundada el 22 de diciembre de 1958, inició actividades en octubre de 1959, con el objetivo primordial de garantizarle al caficultor mejor calidad y un precio justo para el café producido, lo primero desde la iniciativa de organización de una central de beneficio y lo segundo con la financiación de la Federación de Cafeteros y el Banco Cafetero. La creación de esta cooperativa contó con las orientaciones de Francisco Luis Jiménez, quien narró la experiencia de creación:

la Federación Nacional de Cafeteros, me llamó para que hiciera el estudio [...] esto para mí fue un rayo de luz que me iluminaba en una gran inquietud que yo tenía en relación con los caficultores del país, especialmente los pequeños que, según datos, se acercaba a la alarmante cifra de quinientos mil. Quería aprovechar esta ocasión, para no perderla... primero hice un estudio sobre la importancia que tenía para el cafetero colombiano asociarlo en cooperativas... le puse una gran atención al estudio socioeconómico con base en una encuesta a los productores y visité 20 plantaciones para conversar con los dueños de ellas. Elaborado el estudio, la Federación. . . autorizó sin la menor condición, la fundación de la cooperativa [...] Fundada esta entidad y puesta en acción, atrajo la atención... de la Federación, la que me pidió que le fundara una cooperativa en cada región cafetera del país (Jiménez, 2007, p. 121).

El proyecto siguiente en la creación de una cooperativa de caficultores tuvo como escenario la población de Calarcá, en el departamento del Quindío, municipio identificado por su abundante producción cafetera, merced a que más de $80 \%$ de la población se dedicaba a la producción del grano. La cooperativa de Calarcá fue fundada entonces el 6 de agosto de 1960, también con el acompañamiento de Jiménez Arcila y la promoción de Otto Morales Benítez, ministro de Trabajo. 
Luego, la mirada se ubicó en el departamento del Valle del Cauca, creándose en febrero de 1961 la Cooperativa de Caficultores de Sevilla, en la población del mismo nombre. Esta cooperativa abrió prontamente una sucursal en el municipio de Caicedonia, y de ella se destacan los proyectos que para el desarrollo comunitario se pusieron en marcha y que contribuyeron a la pacificación de esta región, afectada por la violencia política partidista de mediados de siglo en Colombia. También en territorio valluno se creó en el municipio de Restrepo, la Cooperativa de caficultores en noviembre de 1961.

El proyecto de creación de cooperativas de caficultores continuó con la apertura de varias de ellas en distintas regiones y localidades de Colombia. Así, entre los años 1960 y 1962 se fundaron cooperativas de caficultores en Ibagué y Líbano (departamento del Tolima), en Popayán (departamento del Cauca), en Manizales (departamento de Caldas), en Sandoná (departamento de Nariño) y en Viotá (departamento de Cundinamarca).

Dentro de esta cronología, merece especial atención la experiencia de creación de cooperativas de caficultores en el departamento de Antioquia, donde una vez establecidas las principales variables macroeconómicas del nuevo acuerdo político denominado Frente Nacional, la dinámica promocional del Estado se orientó hacia la formación de cooperativas agropecuarias y de transportadores. Así fue como con el patrocinio de la Federación Nacional de Cafeteros y su Comité Departamental en Antioquia, se dio vía a las primeras cooperativas de caficultores en distintos municipios del suroeste antioqueño como Andes, Salgar, Jericó y Fredonia, con el objetivo de propiciar un mejor nivel de vida para el campesino caficultor.

Estos procesos fundacionales fueron direccionados desde el comité departamental de cafeteros de Antioquia, que observa como importante la preparación previa de sus dirigentes y administradores, tarea que también le fue encomendada a Francisco Luis Jiménez, quien en 1961 inició la formación de un grupo de jóvenes, entre los cuales estarían posteriormente los gerentes, tesoreros y promotores de varias de las cooperativas de caficultores de la región. Al respecto Francisco Luis Jiménez (2007):

Recordaba entonces mi profunda vinculación con los caficultores de Colombia, cuando hice los estudios con conocimiento directo, en los diálogos y trato íntimo con los pequeños productores para fundar las cooperativas, lo que tuvo lugar mediante estudios profundos de la realidad cafetera del país y la preparación de un personal para dirigirlas, administrarlas y controlarlas.

He hecho una especie de balance, más bien de carácter social y de consistencia histórica en la transformación del país, para llegar a la conclusión de que hoy [año 2000] la situación de los pequeños caficultores es más precaria de lo que era en la década del 60 (Jiménez en Zabala y Arboleda, 2007, p. 207).

Simultáneamente a la creación de las cooperativas de caficultores en Antioquia y ante la necesidad de complementar la labor de las cooperativas de productores -los cultivadores de café también cosechaban otros productos que requerían diversos insumos y técnicas de cultivo-, se decidió conformar la Cooperativa Cafetera Central de Distribución y Consumo, que fue fundada en Medellín el 12 de septiembre de 1962, con el propósito de que en términos de un lustro, se convirtiese en una federación económica, cuyos socios únicamente serían cooperativas de primer grado o federaciones regionales, intencionalidad esta que no se logró, convirtiéndose con el tiempo dicha central en una cooperativa de consumo conocida como Supermercado Cafetero. 
De esta manera las cooperativas de caficultores, con el apoyo institucionalizado de la Federación Nacional de Cafeteros de los comités departamentales de cafeteros, se conformaron en los grupos más organizados y consolidados de las organizaciones de su naturaleza en Colombia. Y desde la década de 1960, se estableció para ellas un régimen especial contenido en las resoluciones 8 y 14, de 1965 y 1968, respectivamente, en las que básicamente se reglamentaban los vínculos entre la federación y las cooperativas de caficultores, en lo relacionado con la consignación en los estatutos de dichas cooperativas de la función de servir de agentes de la Federación Nacional de Cafeteros para las compras de café, así, el cumplimiento por parte de las cooperativas de lo dispuesto en estas normativas, les garantizaba el apoyo de la federación.

En este contexto de creación de las cooperativas cafeteras, entre las décadas de 1950 y 1960 , cabe mencionar algunos hechos significativos. La violencia bipartidista de mediados del siglo xx, cuando desde 1946 el país se convirtió en escenario de una serie de retaliaciones entre campesinos liberales y conservadores, que se agudizó luego del asesinato de Jorge Eliecer Gaitán en 1948 y que se prolongó durante una década; esta lucha entre los partidos provocó una guerra civil, la formación de las guerrillas liberales y el empleo de la fuerza pública como arma a su favor por parte del conservatismo, dándose entre todos estos bandos, las manifestaciones más cruentas y sangrientas que golpearon fuertemente a regiones como el Tolima, el Viejo Caldas y el Valle del Cauca, dejando como resultado cerca de 300000 muertos. Para el caso de Antioquia:

la zona más asociada con la violencia partidista fue la del suroeste, pero el clímax que caracterizó a la región fue el de normalidad por el miedo que tenían los campesinos de manifestar su ira. Los terratenientes, dueños de las grandes extensiones de tierras cafeteras sabían que era necesario contener los posibles brotes de inconformidad liberal campesina en el departamento. Sólo hasta 1950 fue que la violencia vino a manifestarse en esta región (Posada, 2009, p. 1).

En este contexto de violencia se indica que como efectos en las zonas cafeteras se dio la fragmentación de las grandes haciendas, "mediante la conformación de pequeñas explotaciones o de tamaño mediano, (entre diez o quince hectáreas), que aumentaron sustancialmente en número y superficie entre 1950 y 1960" (Bejarano, 1989, pp. 163-164). En general los proyectos del cooperativismo agropecuario, entre ellos los de las cooperativas de caficultores, que se venían fortaleciendo, se vieron afectados por el fenómeno político que se dio en la década (1946-1956), ya que:

Las acciones violentas, que tuvieron su escenario principal en los campos colombianos, aportaron, además del crecido número de muertos, la creación de nuevos factores de recomposición de la vida económica y desequilibrio social, tales como la concentración de la propiedad, la introducción de las relaciones capitalistas en el campo, el abandono de las tierras y la migración a las ciudades. La intervención del Estado durante estos años fue efímera y estuvo centrada en una línea de supervisión intervencionista ejercida por la Superintendencia de Cooperativas de Colombia (Zabala, 2016, p. 50).

La crisis económica, que se da en el país causada en gran parte por la devaluación en los precios del café ocurrida en el año 1962, de acuerdo con Arango (2015, p. 83), "provocó un descenso vertiginoso en las reservas internacionales y afectó el déficit fiscal; además se aumentaron el desempleo y la inflación y se produjo una gran agitación social, especialmente durante el gobierno del presidente Guillermo León Valencia (1962-1966)”. 
Pasadas las épocas del enfrentamiento bélico, a partir del año 1960, el sector cooperativo experimenta procesos de integración, fortalecimiento y mejor estructuración merced al fomento de la Federación Nacional de Cafeteros, que posibilitó a las cooperativas actuar como agentes de compra del grano. De esta manera, "en 1970 funcionaban en el territorio nacional 38 de estas cooperativas, con 69564 socios, realizando operaciones que superaron los 1873 millones de pesos. En 1973 eran 43 cooperativas con cerca de 100000 socios; en este mismo año, estas cooperativas participaron con $66 \%$ de las exportaciones de café" (Zabala, 2016, p. 52).

Para mediados de la década de 1980 existían en Colombia 48 cooperativas de caficultores, 37 de las cuales estaban concentradas en regiones y departamentos destacados en la producción del grano como Antioquia, Valle, Caldas, Cundinamarca, Tolima y Norte de Santander. Estas cooperativas contaban con una capital de 1150000 pesos colombianos, realizaban compras de café aproximadamente por 559457 toneladas y participaban en la exportación con cerca de 443478 toneladas. Este momento de la historia es marcado por un hecho inesperado como fue el rompimiento del pacto internacional del café, acaecido en junio de 1989 cuando por decisión de los países compradores del grano, se desconocieron las cuotas reguladas en el acuerdo internacional del café, lo cual implicó el regreso a la ley de oferta y demanda, provocando el desplome de la economía cafetera.

Un estimativo de la época señala que, en un año, los países productores ya habían perdido unos 6000 millones de dólares por los bajos precios. Aunque se llegaron a proponer fórmulas como la retención de la producción nacional para disminuir la oferta en el mercado mundial, nada detuvo que empezara a abrirse paso una época de apremios. Como si fuera poco, a la pelea por los mercados se sumaron países como Vietnam, Etiopía o India, con lo cual también se perjudicaron los precios del grano 2

El impacto que sufren los productores del grano a causa de las reformas neoliberales a finales de la década de 1980, influirá, según Ramírez (2008, p. 114), "en la gestación de un fuerte movimiento social campesino, que reivindicó principalmente la condonación de sus deudas".

Dicho movimiento consistió en que, a raíz de toda la crisis cafetera generada, en la que entre otros aspectos se dio la disminución de los ingresos de pequeños y medianos caficultores, como también del precio internacional del café y del patrimonio del Fondo Nacional del Café y a su vez el alza en el precio de los fertilizantes y la aparición de la broca, los caficultores se vieron en la necesidad de endeudarse con préstamos bancarios y extra bancarios, razón por la cual, y a petición de los caficultores, se expidió la ley 34 de 1993 relacionada con el refinanciamiento de la deuda, lo que finalmente no significó ninguna mejoría, sino que triplicó el monto de la deuda. En consecuencia, se expide en 1993, la ley 101 "de carácter tributario, y que contiene artículos que, por primera vez en la historia moderna del país, tratan la condonación de deuda [...] previo la condonación hasta por 3 millones de pesos" (Ramírez, 2008, p. 117). Posteriormente, la ley 223 de 1995 condonó hasta por 5000 000, lo que favoreció a 28 \% de los deudores nacionales.

Durante la década de 1990 y los primeros años del siglo xxi, la influencia de la Federación Nacional de Cafeteros aún es significativa en el desarrollo de las cooperativas, así lo corrobora Francisco L. Jiménez:

${ }^{2}$ El Espectador, 27 de febrero de 2013. 
Al llegar las cooperativas de caficultores al año 2000, no hay la menor duda de que gracias a la colaboración de la Federación Nacional de Cafeteros y de los comités departamentales, aparece una obra, un resultado que merece el mejor reconocimiento y una definitiva aprobación para los que están dedicados a la producción y comercialización del grano. Sin duda alguna es una sólida expresión de las cooperativas del agro y constituye, por tanto, un ejemplo de lo que pueden las organizaciones sin ánimo de lucro, que solo buscan el bienestar de los socios y de la comunidad (Jiménez, 2002, p. 111).

Sin embargo, existen situaciones que han generado crisis en la economía de producción del grano, cuando los precios han disminuido y los costos de producción y mantenimiento han aumentado, lo mismo que el valor de la canasta familiar del campesino cultivador; esto aunado a la arrasadora situación de violencia que ha provocado el abandono de las parcelas rurales y el desplazamiento hacia las urbes.

Derivado de lo anterior, también durante este periodo de comienzos de la década de los años 2000 , las cooperativas de caficultores presentaron debilidades que generaron momentos de declinación, y que se manifestaron en cierto desinterés de la Federación hacía las cooperativas, un claro ejemplo fue la desaparición del departamento que, adscrito a la propia Federación, daba acompañamiento y asistencia a las cooperativas, así como de la Fundación Educativa denominada Granja Esteban Jaramillo que, años atrás, había sido creada en el municipio de Venecia (departamento de Antioquia) para impartir acciones de fomento y enseñanza en todo lo relacionado con la producción del grano de café.

Ante este panorama, las recomendaciones desde la alta directiva del sector caficultor en Colombia, se orientaron hacia el replanteamiento de la industria cafetera en la perspectiva de la innovación y el cambio, recomendaciones que las cooperativas del gremio han buscado atender a través de la federación nacional y los comités departamentales de cafeteros, lo que ha facilitado la fusión de las cooperativas, para conformar entidades más fuertes, con capacidad suficiente para una nueva actividad que enfrente las circunstancias del momento y que tengan la suficiente preparación para el desarrollo de una adecuada acción social.

En este sentido, es pertinente presentar el análisis del fundador de estas cooperativas: "El fin de este mensaje es poneros de presente [...] que las Cooperativas de Caficultores de Colombia, en presencia de la actual situación de la industria del café [...] y sus tropiezos en las relaciones internacionales, sobre todo y teniendo muy en cuenta la angustia de los pequeños productores, son las que tienen con su capacidad de acción la salvación cafetera, y desde luego lo que constituye para ellas una gran responsabilidad" (Jiménez, 2002, p. 114).

En el transcurrir de los acontecimientos descritos, estas formas empresariales cooperativas, actualmente, son organizaciones adscritas a la economía solidaria ${ }^{3}$ donde sus dueños son los productores de café asociados a la cooperativa, la cual les garantiza la compra de la cosecha cafetera en el mayor número de puntos de atención, transfiriendo el mejor precio posible del mercado al productor. Algunas cifras importantes sobre estas formas empresariales de la economía solidaria muestran que entre 2015 y 2017 el número de cooperativas de caficultores en Colombia son 33,

\footnotetext{
${ }^{3}$ Dicha economía se define como sistema socioeconómico, cultural y ambiental conformado por el conjunto de fuerzas sociales organizadas en formas asociativas identificadas por prácticas autogestionarias solidarias, democráticas y humanistas, sin ánimo de lucro para el desarrollo integral del ser humano como sujeto, actor y fin de la economía. (Colombia. Congreso de la República. Ley 454, 1998).
} 
las cuales han mantenido una base social de 82000 asociados. Específicamente en el Departamento de Antioquia son cinco las cooperativas de este tipo, las cuales para el periodo en mención han contado con un capital social aproximado de 29228 millones de pesos (Benjumea, 2015; Cooperativa de Caficultores de Andes, 2018).

\section{COOPERANDES: UNA EXPERIENCIA REPRESENTATIVA DEL GOOPERATIVISMO CAFICULTOR EN ANTIOQUIA}

\section{Orígenes y trayectoria socio histórica}

Andes es un municipio fundado en 1852, localizado en la subregión del suroeste del Departamento de Antioquia, a $117 \mathrm{~km}$ de la ciudad de Medellín; su economía se basa principalmente en la caficultura; según el censo del 2005 cuenta con 41591 habitantes, de los cuales en la cabecera municipal hay 19176 habitantes y en el sector rural 22415 habitantes. Es la población que hace más de medio siglo vio nacer a Cooperandes, cooperativa de caficultores constituida el 14 de junio de 1961, la cual obtuvo personería jurídica reconocida mediante resolución 0750 del mismo año, emitida por la entonces Superintendencia Nacional de Cooperativas, que posteriormente pasó a denominarse Superintendencia de Economía Solidaria.

$\mathrm{El}$ proceso fundacional de Cooperandes tuvo sus antecedentes desde finales de la década de 1950, cuando el café tomaba gran fuerza en la economía nacional, y los cultivadores del grano eran víctimas de los denominados agencistas, que pagaban el café de acuerdo con sus intereses personales. Fue así como en 1961, con base en un proceso de fomento de la Federación Nacional de Cafeteros de Colombia, 41 caficultores de los municipios de Andes, Betania y Jardín, ubicados en el suroeste antioqueño, decidieron unir sus esfuerzos para crear una organización que contribuyera a cimentar su patrimonio, permitiera mejorar sus condiciones de vida y optimizará -a la vezla producción agrícola. Desde entonces ha existido un alto grado de significancia de la cooperativa caficultora en la gestión e impulso del desarrollo económico, social y cultural del municipio y de la subregión.

La fundación de la Cooperativa de Andes es parte de un esfuerzo de organización asociativa de los productores de café que se inicia mediante un proceso de fomento de la Federación de Cafeteros de Colombia en un momento de superación de la crisis política colombiana y de acuerdos para superar factores de violencia sobre todo en los territorios de más alto nivel de producción del grano. La federación está constituida por productores independientes quienes participan de un proceso democrático para la elección de sus representantes en los comités municipales y departamentales; sus objetivos son la representación y defensa del productor de café, la negociación de precios internacionales y velar con mantener buenas condiciones de vida para sus miembros. Dentro de esta última perspectiva fue importante garantizar formas democráticas de base, tal como las cooperativas, que fueran cercanas al productor y que, a su vez, irrigaran sus beneficios en pro del desarrollo de los municipios y las zonas rurales.

El acuerdo cooperativo, con base en el cual se inició y se mantiene en operación la entidad, ha tenido como objetivo central promover y mejorar permanentemente las condiciones económicas, sociales y culturales de los asociados, en procura del desarrollo integral de los mismos. En cumplimiento de este objetivo, presta a sus asociados los siguientes servicios: comercialización de café, industrialización, exportación, comercialización de insumos agrícolas, materiales y bienes en general, crédito, educación, bienestar social y las demás que ameriten su expansión y desarrollo. 
Así pues, la Cooperandes es una cooperativa multiactiva que se ha puesto históricamente al servicio de los caficultores de la región del suroeste del departamento de Antioquia. A través de los años ha alcanzado un importante grado de estabilidad financiera y administrativa, constituyéndose en una de las organizaciones de este tipo con más dinamismo en el concierto nacional, siendo hoy en día la cooperativa del sector caficultor con mayor capacidad financiera y con la más alta incidencia en el desarrollo de los territorios en los cuales adelanta su acción. Este proceso de consolidación y expansión se ha verificado a tono con los requerimientos del entorno macroeconómico y la regulación estatal.

En cuanto a la base social, puede decirse que esta se mantuvo en crecimiento por espacio de varias décadas, lo que ha dado a la cooperativa un carácter de mayor representatividad frente a otras organizaciones de su misma naturaleza en la región (cooperativas de caficultores de los municipios de Fredonia, Salgar, Jericó y la del Norte de Occidente) (véase cuadro 1 ).

Cincuenta años después de su fundación, es decir, al cierre del año 2011, la cooperativa cuenta en su área administrativa con 156 empleados, que atienden las necesidades de 3869 asociados; todos ellos dedicados a la actividad de caficultura en la región, de donde puede decirse que través de los años, ha mantenido una base social estable, que aunque de carácter cerrado en cuanto a su actividad económica, le ha permitido mantener igual estabilidad en las cuentas patrimoniales, esto pese a que se haya dado una disminución en la base social durante los últimos años (véase cuadro 2).

Entre 2007 y 2015 , el número de asociados ha experimentado ligeras variaciones, con una disminución sostenida hasta 2014 y recuperación en 2015. Esta situación de descenso en el número de asociado está directamente relacionada con la crisis de producción que manifestó el sector caficultor a partir de 2008: en 2007 se produjo el más alto nivel de producción de la primera década de siglo xxi, pero el volumen de sacos de café presentó un descenso inmenso llegando 2012 a $40 \%$ de la producción que se había generado en 1990; apenas recuperado positivamente en 2015. Esta disminución se produjo como consecuencia de factores climáticos y los desestimulos en el precio de los mercados internacionales. Consecuentemente, muchos productores asociados no pudieron dar cuenta de sus compromisos de cuotas de café que definían las normas internas de la cooperativa, lo que condujo a su retiro como asociados y a buscar alternativas de ingresos mediante otros productos agrícolas. En especial, las variaciones internacionales en el precio del café y la falta de sustentación en el precio interno han generado que una gran mayoría de nuevos asociados apenas cumplan con una producción mínima para ajustarse a los requisitos de afiliación a la cooperativa.

En la actualidad, a partir de datos de junio de 2018 la cooperativa cuenta con 3539 asociados, de los cuales 1044 son mujeres, entre ellas 233 cabeza de familia. El promedio de edad de los asociados es de 55 años (Cooperandes 2018). La cooperativa está manifestando, en su nivel asociativo, una crisis generacional; no existe una renovación de nuevos asociados que sustituyan los viejos productores: situación que se explica por el hecho de que la producción de café en este territorio corresponde a economías familiares que son sostenidas por una tradición de muchas décadas, y los jóvenes (en una gran mayoría) vienen abandonando sus terruños buscando nuevas alternativas de ingreso y mayores oportunidades de crecimiento personal y económico en otras áreas productivas o desplazándose hacia la ciudad capital. La Cooperativa viene haciendo esfuerzos por evitar el desplazamiento de la juventud mediante programas diversos, entre ellos en el de 


\section{CUADRO 1. COOPERATIVAS DE CAFICULTORES EN ANTIOQUIA, NÚMERO DE ASOCIADOS, 1972-1982}

\begin{tabular}{lrrr}
\hline Cooperativas & $\begin{array}{c}1972 \\
\text { Total base social }\end{array}$ & $\begin{array}{c}1982 \\
\text { Total base social }\end{array}$ & Variación \\
\hline $\begin{array}{l}\text { Cooperativa de Caficultores } \\
\text { de Fredonia }\end{array}$ & 2283 & 2592 & 309 \\
$\begin{array}{l}\text { Cooperativa de Caficultores } \\
\text { de Salgar }\end{array}$ & 1616 & 2201 & 585 \\
$\begin{array}{l}\text { Cooperativa de Caficultores } \\
\text { del Norte y Occidente }\end{array}$ & 2023 & 3336 & 1313 \\
$\begin{array}{l}\text { Cooperativa de Caficultores } \\
\text { de Jericó }\end{array}$ & 2250 & 1753 & 497 \\
$\begin{array}{l}\text { Cooperandes } \\
\text { Totales }\end{array}$ & 2439 & 3497 & 1058 \\
\hline
\end{tabular}

Fuente: Vázquez (1985, p. 77).

generación de proyectos productivos de mayor valor agregado, o apoyando procesos de desarrollo en las localidades que influencia; pero de mantenerse la tendencia de envejecimiento del productor asociado, la cooperativa podrá tener dificultades en su nivel de asociatividad en la próxima década.

En este sentido de la base social de la organización también es importante indicar que los asociados de la Cooperandes han presentado una condición claramente especificada que se evidencia en el contenido del artículo 10 de sus estatutos, sobre condiciones de admisión para personas naturales: $a$ ) las personas legalmente capaces, honradas y con buenas costumbres, que acrediten previamente su vinculación con zonas de influencia cafetera en calidad de propietarios, poseedores o tenedores legítimos de predios destinados a la producción del café, y $b$ ) podrán así mismo ser asociados los menores de edad que hayan cumplido catorce años, o quiénes, sin haberlos cumplido, se asocien a través de su representante legal siempre que acrediten su calidad de propietarios o de legítimos poseedores de fincas cafeteras (Cooperandes, 2018).

En cuanto a lo que tiene que ver con el área de influencia de la cooperativa (municipios de Andes, Betania, El Carmen de Atrato, Ciudad Bolívar, Hispania y Jardín) se encuentran 35000 hectáreas dedicadas a la producción del café; esto es, aproximadamente 6200 predios en los que el promedio de tierra por finca es de 2.52 hectáreas y el promedio de tierra por familia es de 5.9 hectáreas y $62 \%$ de los agricultores están afiliados (Cooperandes, 2018).

\section{Desarrollos socioeconómicos}

En lo relacionado con el proyecto socio económico, la Cooperandes, fiel a su propósito de mejoramiento de la vida campesina, ha identificado en su estatuto un objeto social preciso: "promover y mejorar permanentemente las condiciones económicas, sociales y culturales de los asociados, procurando el desarrollo integral de los mismos. Buscará con su acción no sólo el beneficio del asociado, sino el de los miembros de su familia, el desarrollo de la comunidad y de la región donde opera" (Cooperandes, 2018). 


\section{GUADRO 2. RESUMEN DE LA COMPOSICIÓN ASOCIATIVA DE COOPERANDES PERIODO, 2007-2015}

\begin{tabular}{lrrrrrrrrr}
\hline & 2007 & 2008 & 2009 & 2010 & 2011 & 2012 & 2013 & 2014 & 2015 \\
\hline Asociados & 4335 & 4255 & 4141 & 3950 & 3869 & 3569 & 3601 & 3455 & 3591 \\
$\begin{array}{l}\text { Empleados } \\
\begin{array}{l}\text { Crecimiento } \\
\quad \text { de asociados }\end{array}\end{array}$ & 141 & 151 & 147 & 157 & 156 & 173 & 183 & 252 & 252 \\
$\begin{array}{l}\text { Crecimiento } \\
\text { de empleados }\end{array}$ & 0 & -1.85 & -2.68 & -4.61 & -2.05 & -7.75 & 0.90 & -4.05 & 3.77 \\
\hline
\end{tabular}

Fuente: Estados financieros de entidades solidarias 2007-2015, en Colombia. Superintendencia de Economía Solidaria (2016).

Para cumplir con dicho objeto, la Cooperativa ha desarrollado un conjunto de actividades productivas y servicios, relacionas con la comercialización, la industrialización y la exportación del café. La comercialización realizada a través de los puntos de compra de café y las tiendas Café de los Andes; la industrialización a través de puntos de trilla y mejoramiento de calidad, y la exportación que se realiza directamente o a través de mecanismos dispuestos por la Federación Nacional de Cafeteros de Colombia.

Otras actividades orientadas al cumplimiento del objeto social son a) la comercialización de insumos agrícolas, materiales y bienes en general, proceso que se efectúa mediante la disposición de almacenes en los diferentes municipios; $b$ ) el crédito que es atendido de manera especializada en la sección creada para este efecto y $c$ ) la educación que se operativiza a través del área de bienestar social de la cooperativa.

\section{Comercialización de café}

Como ya se ha dicho, la principal actividad de las cooperativas cafeteras es la compra de café, la cual realizan a entidades asociadas o a otras que no lo son -aspecto que no es distinto en Cooperandes (véase cuadro 3).

$\mathrm{Al}$ cierre de 2011 la cooperativa cuenta con 17 puntos de servicio, todos cercanos a los sitios de producción. Es el servicio más importante y mejor valorado por los asociados, porque, además, de esta manera, se cumple con una función reguladora de precios y estabilizadora del ingreso campesino, contribuyendo así al mejoramiento de condiciones y calidad de vida de esta población. Los puntos de servicio son establecimientos ubicados en los diferentes municipios en los cuales la cooperativa cuenta con asociados, haciendo cercano el proceso de acopio del café, evitando costos de desplazamiento pero, sobre todo, contribuyendo a que los valores agregados sean ubicados en los mismos territorios en los que se genera la producción; situación que se ha visto mejorada en el 2018 con el Programa Buen Precio mediante el cual se busca sostener, garantizar y proteger el precio de la carga de café mejorando así la rentabilidad del caficultor asociado. 


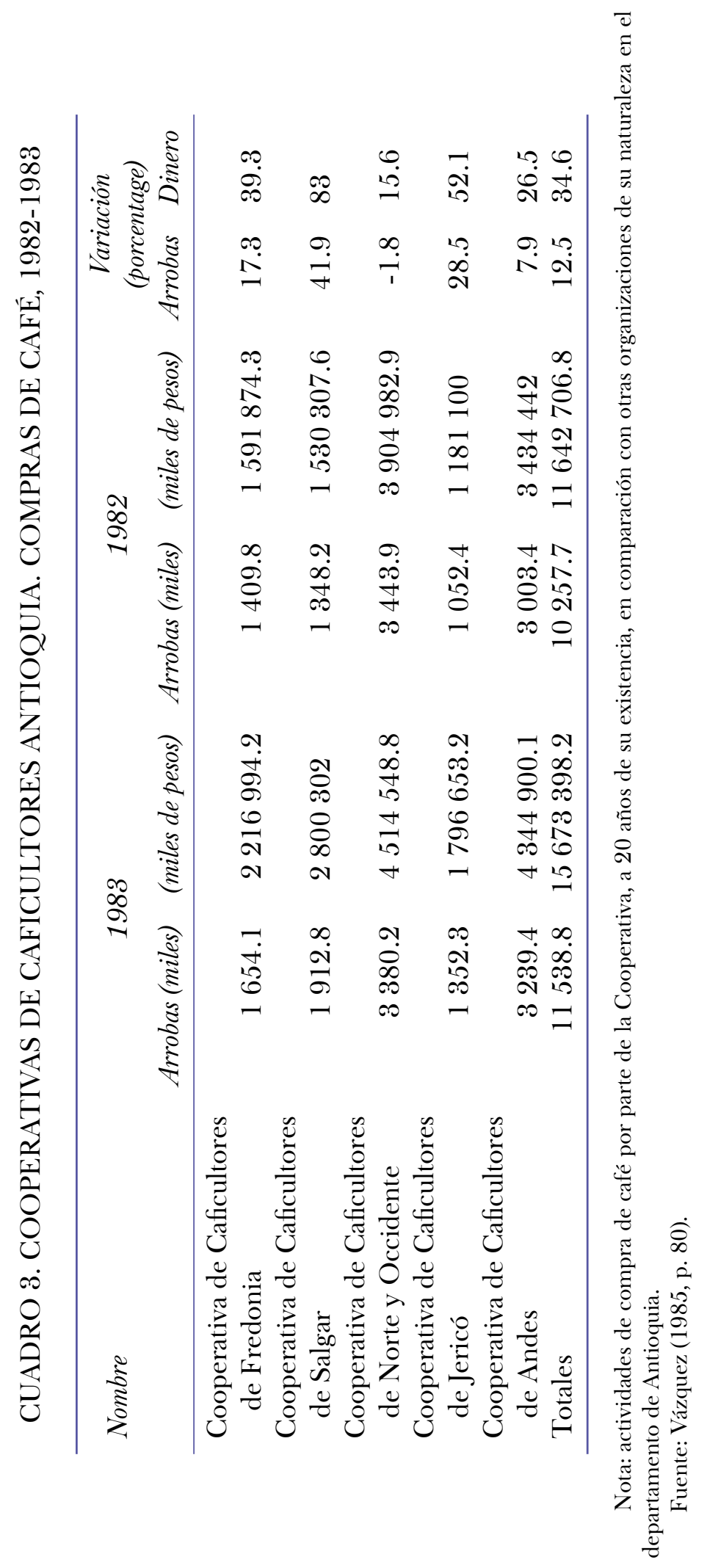


Por su parte, también en el momento referido al cierre del 2011, las operaciones de comercialización del café tendieron a aumentar en la medida del incremento en la producción, por efecto de la introducción de elementos innovadores. Lamentablemente, la Cooperativa debió realizar dichas operaciones con intermediarios financieros ajenos a su circuito económico. Para la compra del café a sus propios asociados o productores no asociados, debieron destinarse recursos de liquidez que estaban por fuera de su propio balance e ingresan a la economía de las instituciones financieras no cooperativas.

Esta situación se profundizó para comienzos del año 2014, cuando empiezan a operar las previsiones de la ley 1430 de 2010, por medio de la cual se dictaron normas tributarias relacionadas con la competitividad productiva colombiana, que incentivaron las operaciones electrónicas para las transacciones productivas, mediante la utilización del sistema financiero autorizado.

En cuanto a la comercialización del grano, con 29900000 kilos de café en 2014, la Cooperandes continuó siendo dentro de las cooperativas de su índole, la mayor compradora del grano, para lo cual destinó 180479 millones de pesos y con ello, se ha escalafonado dentro de una de las mayores exportadoras del grano.

[La Cooperandes] ha desarrollado estrategias en servicio, así como convenios, planes de fidelización, entre otros, con lo que ha ganado participación en un mercado cada vez más competido, logrando ubicarse entre los doce primeros exportadores de café en Colombia, según el escalafón de la federación.

Las exportaciones directas, a 37 puertos de doce países, sumaron 184531 sacos de café verde que permitieron trasladarle un mejor precio al productor. Este mercado registró el 58.5 por ciento de las ventas del año.

Otra de las iniciativas exitosas es la compra de contratos de futuro, esquema que permitió negociar 4.9 millones de kilos de café, y para el presente año los contratos ya suman más de 4.7 millones de kilos (Arias, 2015).

El anterior aspecto es importante relacionarlo con lo que constituye la cadena de valor internacional del café, la cual puede describirse como el conjunto de eslabones o actividades necesarias para generar el grano, es decir, que es una cadena que comprende desde el inicial proceso de producción hasta la venta final, incluyendo también el reutilizamiento de los residuos. Dicha cadena implica una nueva forma de funcionamiento y organización de las redes transnacionales y es orientada por la demanda "puesto que las grandes compañías comercializadoras se encuentran jalonando la cadena al monopolizar la comercialización final del café procesado [...] Una vez el grano es comprado e importado del país de origen, empiezan los dominios del segundo mercado del café" (García y Olaya, 2006, p. 210). Las actividades que conforman el eslabón del abastecimiento son las siguientes: comercializadoras internacionales de café verde, operador logístico internacional, industria torrefactora internacional, comercializadoras internacionales de café procesado, asociaciones y organizaciones internacionales.

Sobre la cadena de valor internacional del café, Kaplisky (2004) reflexiona acerca del rol de los actores en la misma, dejando ver la débil participación de los cultivadores:

Históricamente, cuatro actores principales han tenido roles en la cadena de producción del café. Los granjeros obviamente han sido el centro de la cadena [...], la mayoría de estos cultivadores han estado operando a escala pequeña o mediana. En la mayoría de 
los países productores, el segundo actor de importancia ha sido una de varias formas de organización del mercadeo y asociaciones de productores, quienes han sido responsables por muchas de las actividades no relacionadas con la recolección del grano en los países en desarrollo: molido, compra, exportación y así sucesivamente. El tercer actor han sido los comerciantes globales, obteniendo café de una variedad de orígenes y vendiéndoles al cuarto actor principal de la cadena, los tostadores, quienes ponen la marca y la distribución (Kaplisky, 2004, p. 9).

En este mismo sentido, Pérez (2013, p. 557) señala: "Los países con un bajo nivel de ingreso no han podido concentrar su actividad económica en la parte lucrativa de la cadena de valor del negocio cafetero como es la del procesamiento, transporte y distribución mayorista del café, y en los supermercados de barrio con población migrante o tiendas minoristas, restaurantes y cafeterías especializadas".

Así, con el fin de dinamizar la participación de los países productores y dar equilibrio a la cadena de valor, se propone como una de las estrategias la posibilidad de que en la parte final de la misma, se pueda acceder al denominado mercado detallista o cadena de distribución detallista, entendido esto como todas las actividades que intervienen directamente en la comercialización o distribución del producto a los consumidores finales para su uso personal, y luego de ello "ingresar a prácticas comerciales como el fair trade, del cual dependen muchos productores, especializados en la producción de café orgánico, o en la venta de café en taza, como en el caso del café distribuido en las tiendas Juan Valdez, puede ayudar a incrementar la participación en la cadena internacional de valor del café" (Pérez, 2013, p. 556).

\section{Industrialización del café}

La cooperativa cuenta con la trilladora La Pradera (municipio de Andes), inaugurada el 5 de julio de 2003. Su capacidad de producción es de 800 sacos día y en estos años se han trillado 1542000 sacos, lo que la constituye en un elemento de trazabilidad para los cafés especiales. Los cafés especiales retribuyen con mejores ingresos a los caficultores: $35 \%$ del café comercializado por la cooperativa, corresponde a elementos de calidad para la exportación. Dentro de este campo, se tiene la alianza con Nespresso (con el apoyo de Expocafé y Caféexport), de la cual se benefician 120 familias de caficultores. Varios de estos cafés especiales se comercializan a través de las tiendas Café de los Andes, lugares en los cuales se incentiva el consumo del café producido del grupo asociado bajo la marca Café Citará, ubicadas en diferentes lugares de la región (Andes, Jardín y Ciudad Bolívar) y en la ciudad de Medellín (Cooperandes, 2010, 2011).

Almacenes de provisión agropecuaria

Se cuenta con 18 almacenes de café, con una canasta básica cafetera, que busca productividad en los cultivos. Estos almacenes se ubican en diferentes municipios, en algunos de los cuales se han organizado con base en alianzas con la Cooperativa de Caficultores de Salgar, Urrao; la Cooperativa de Caficultores de Antioquia, Jericó, y la Comercializadora J. M. Estrada, Medellín. 
En cada almacén se cuenta con gran variedad de productos en diferentes líneas: hogar, construcción, agroquímicos, concentrados, entre otros. La calidad de estos ha generado la fidelización de los consumidores. En estos almacenes se generan 50 empleos directos. Esta área se ha convertido en una poderosa unidad de negocios que genera mejor calidad de vida para los asociados, la familia y la comunidad.

Servicio de crédito

A poco más de sus 20 años de existencia, en 1983 la cooperativa sin ser propiamente una entidad de ahorro y crédito, ni tener organizada esta sección facilitaba crédito a sus asociados, "durante el año 1983 otorgó 1078 préstamos por un valor 21446.2 millones de pesos” (Vázquez, 1985, p. 83). Para 2011, el total de cartera era de 14098687044 billones de pesos (Cooperandes, 2010, 2011).

En los últimos cinco años, estos créditos se otorgan a los asociados, con bajas tasas de interés y con fáciles accesos, contribuyendo con ello al mantenimiento del proyecto productivo y a satisfacer necesidades básicas.

Servicios Sociales: solidaridad y educación

Para la década de 1980, la cooperativa prestaba el servicio de auxilio en dinero para que los asociados y sus familias pudieran cubrir gastos en salud: médicos, medicinas, hospitalización y consultas odontológicas; en 1983 esos auxilios en dinero y los servicios señalados alcanzaron en la cooperativa un rubro de 5656.10 sin contabilizar un seguro de vida para el socio y su cónyuge que la cooperativa otorgaba gratuitamente (Vázquez, 1985, p. 83).

En cuanto al comportamiento de los procesos concernientes a la educación y el bienestar social (inversión social) a partir del año 2000, los logros alcanzados en estas áreas muestran que se contribuye a la calidad de vida de los asociados y las familias, mediante el otorgamiento de auxilios y la formación (cooperativa, técnica y profesional). Así en rubros como educación para el trabajo y el desarrollo humano, educación formal, solidaridad y retorno cooperativo se han efectuado en los últimos años inversiones aproximadas por 15000 millones de pesos colombianos (Cooperandes, 2010, 2011, 2015a). La cooperativa también otorga auxilios para salud, defunción, seguro de vida al grupo familiar, contribuciones y obras, imprevistos y calamidad doméstica, entre otros. En el 2011 se otorgaron 9342 auxilios, por un valor de 298314882 pesos colombianos (Cooperandes, 2011).

En materia educativa, se ha apoyado durante los últimos cinco años la formación de jóvenes, con base en convenios para educación firmados con la Universidad de Antioquia, el Instituto Colombiano de Crédito Educativo y Estudios Técnicos en el Exterior y la Federación Nacional de Cafeteros, por un valor de 2539 millones de pesos colombianos y con los cuales se ha beneficiado a 550 jóvenes.

También, a partir de 2015 en el ámbito educativo, la cooperativa busca el desarrollo económico y social de los caficultores de la región a través del programa Técnicos Promotores Sociales, el cual,

busca apoyar el desarrollo económico y social de las familias cafeteras, por medio de la enseñanza, el aprendizaje y el acompañamiento constante en temas de tecnología, aprovechamiento y uso de los recursos disponibles, asuntos gremiales y organizaciona- 
les, aspectos logísticos y administrativos, y todo tipo de materias que les ayuden tanto a los caficultores como a sus familias a aumentar su producción y sus ingresos y, en consecuencia, a mejorar considerablemente su calidad de vida (Cooperandes, 2015b).

Así, Cooperandes ha mantenido en los últimos quince años un nivel de posicionamiento mayor, en relación con las cooperativas de su misma naturaleza en el departamento de Antioquia, en las variables correspondientes a los activos, patrimonio, capital social y resultados del ejercicio productivo, inclusive llegando a ubicarse entre las diez cooperativas de producción agraria más grandes de Colombia en términos de patrimonio (véase cuadro 4).

\section{Estructura administrativa de la cooperativa}

La cooperativa desarrolla un conjunto de actividades económicas previstas en sus estatutos y con las cuales se propone asegurar el cumplimiento del objeto social; para ello, ha contado con un promedio de 150 empleados en los últimos años, ha establecido una estructura administrativa desde la cual se ha constituido una determinada cultura organizacional en condiciones óptimas de estabilidad. Esta estructura está administrada básicamente por cinco direcciones, cada una con sus respectivas responsabilidades y áreas funcionales. $\mathrm{Al}$ frente del conjunto de la estructura, se encuentra la Gerencia general. Esta estructura ha llevado a que la cooperativa se constituya en una de las empresas de mayor potencial de empleo para toda la región del suroeste antioqueño.

Desde el punto de vista de su desempeño administrativo, la Cooperandes desarrolla este proceso a través de la metodología de la planeación estratégica, que inició a comienzos de este siglo Xxi, con la aprobación del Plan 2002-2004. Este primer plan fue redefinido en periodos posteriores, ajustándose en diferentes momentos. Hoy en día se opera con base en un plan quinquenal que responde a un marco conceptual del entorno nacional e internacional y a grandes lineamientos contemplados en la misión que define la esencia de la organización como "Participar activamente en el desarrollo integral del asociado, su familia y la región"; con una visión como apuesta, en la cual la cooperativa pretende ser hacia el futuro "la mejor alternativa socioeconómica para los caficultores, mediante la eficiente prestación de servicios” y el enfoque estratégico orientado a "[c]onvertir al asociado y a nuevas generaciones de caficultores en empresarios exitosos, a través de una Cooperativa sólida e innovadora, que con talento humano competente y utilizando tecnologías apropiadas, garantice una comunicación efectiva con el asociado y el acceso a instrumentos que le permitan ser el gestor de su propio desarrollo (Cooperandes, 2018)".

El plan está ordenado en líneas estratégicas, que responden a la visión de futuro del grupo asociado con relación a la comercialización del café, la provisión agropecuaria, la sostenibilidad financiera, el talento humano competente, la información, comunicación e innovación, el servicio de crédito y el relacionamiento con asociados.

Además de la consolidación de los procesos productivos que han caracterizado a la cooperativa y de mantener las certificaciones de calidad alcanzadas desde el 2005, el plan contempla proyectos de vital importancia para el futuro, representados en el programa educativo, en la investigación e innovación, el bienestar social y el desarrollo financiero. 


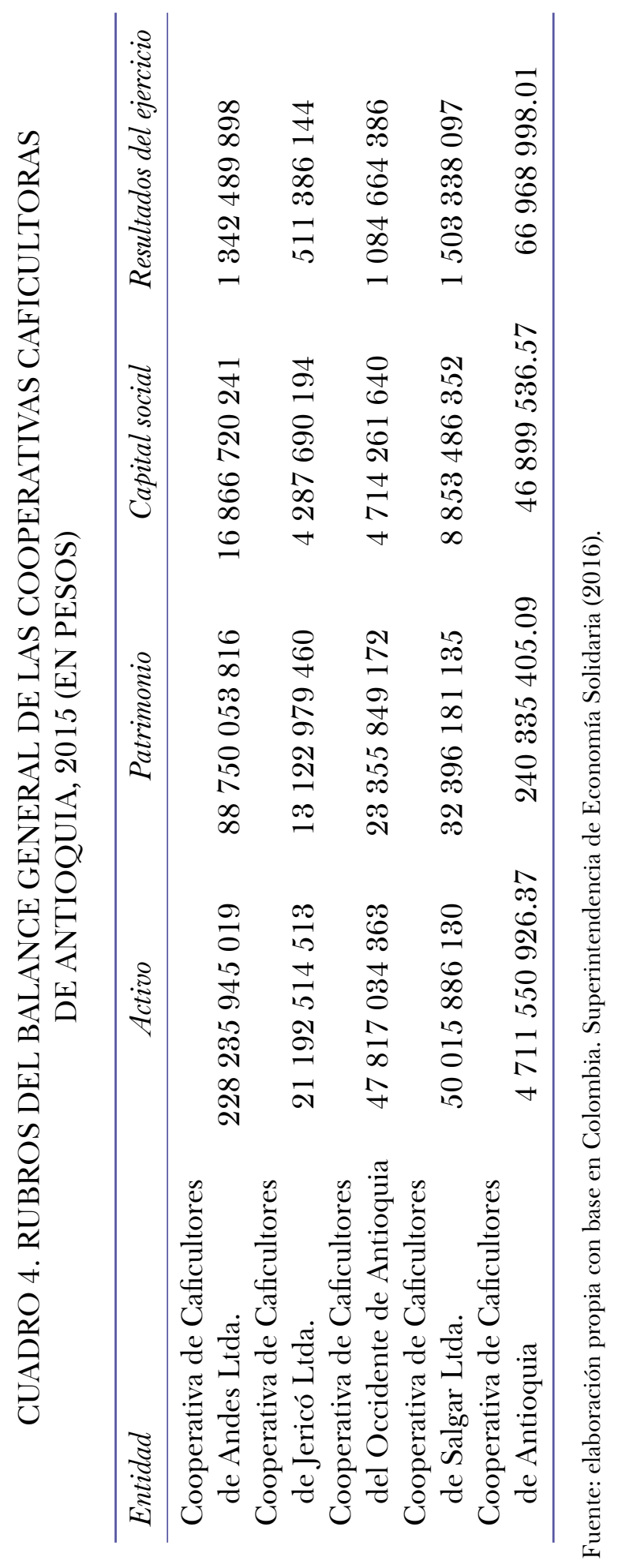


El programa educativo desarrollado con base en una alianza entre el Comité Departamental de Cafeteros, la Fundación Educativa del Café, el Servicio Nacional de Aprendizaje, la Universidad de Antioquia y las demás cooperativas de caficultores de Antioquia, prevé la constitución de la Universidad del Café, con sede en Andes.

La investigación y la innovación concebidas desde la inversión en temas como la pectina del café, materia prima para la industria de alimentos, cosméticos y artículos farmacéuticos contempla la utilización de la pulpa para los concentrados para animales y el mucílago como fuente de nutrición para animales y la producción de etanol.

El bienestar social se ha puesto en marcha con la construcción de las centrales de beneficio y prevé aspectos que redundan en bienestar para todos: más tiempo para compartir en la familia, ahorro en costos, contribución con el medio ambiente, mejor calidad del café y un mercado asegurado.

En cuanto al desarrollo financiero, pensado desde operaciones de ahorro con los asociados como complemento a la labor de crédito que actualmente existe, se contempla una estrategia de conformación de una sección de ahorro y crédito que parta de la confianza y el respaldo económico de los caficultores.

Otro de los proyectos concebidos apunta a la construcción del Parque Industrial del Suroeste Antioqueño, dotado de una zona franca en el triángulo de desarrollo del municipio de Andes (en donde están ubicados los terrenos de Cooperan, Comfenalco y la Universidad de Antioquia) para aprovechar las ventajas tributarias y arancelarias de este mecanismo legal. Allí se tendrá una gran central de beneficio del café, anexa a la actual trilladora, una planta de concentrados, un laboratorio para el estudio de la pectina, una planta industrial del café para la producción de equipos para el agro, una planta para el procesamiento de los cítricos, además de los servicios tradicionales de Comfenalco y las actividades educativas de la Universidad de Antioquia.

Todos estos proyectos redundan en una inmensa contribución de la cooperativa, y sus aliados estratégicos, al desarrollo territorial del suroeste antioqueño. Tales proyectos requieren de una gigantesca inversión en el futuro, así como de la creación de mecanismos de financiamiento propios de los asociados y de la misma cooperativa.

\section{Conclusiones}

Las cooperativas de caficultores han beneficiado y han sido un factor de desarrollo en la sociedad cafetera. Además de forjar y cimentar la forma empresarial cooperativa entre el gremio cafetero representada en la Federación Nacional de Cafeteros.

Así, a partir de lo expuesto sobre el cooperativismo caficultor en general y desde los aspectos reseñados para la Cooperandes, puede concluirse que las cooperativas de caficultores han demostrado que la asociación es un camino adecuado para alcanzar progreso y para el aporte a la solución de necesidades de su población objeto, en la medida en que favorezcan la generación de condiciones de vida y de desarrollo humano para los asociados y para las comunidades en las cuales se encuentran inmersas. Estas influencias se hacen evidentes en aspectos como $a$ ) el asociado caficultor, es considerado la razón de ser de todas las acciones de la empresa cooperativa; $b$ ) el apoyo a sus asociados mediante la prestación de servicios de asistencia técnica, acompañamiento financiero, asesoramiento en las etapas de producción y en la relación con el consumidor; c) la introducción del concepto de calidad a través de programas y capacitaciones especializadas en la producción del café, que ofrezcan a sus asociados en convenios con entidades gubernamentales; $d$ ) el fomento a la 
instauración de tecnologías innovadoras que permitan reducir los costos de producción y mejorar las economías de escalas, como también la coherencia con el cuidado y la protección del medio ambiente, mediante el uso de buenas prácticas como la producción limpia y orgánica; e) el interés puesto en toda la cadena de valor del producto y no exclusivamente en su comercialización y f) la cualificación del talento humano y la capacitación integral a los asociados, en la medida en que subvencionen el acceso y permanencia en los diferentes niveles de educación para las familias de los asociados, contribuyendo así de manera directa a la calidad de vida y al crecimiento económico de la población.

En términos del análisis general de las cooperativas de caficultores de Colombia y Antioquia, puede decirse también que estas instituciones han tenido sostenibilidad en el tiempo, en la medida en que se han aplicado eficientemente a cumplir los objetivos económicos, para los que fueron creadas: la compra de café a los productores y la obtención de excedentes en sus operaciones.

A partir de este sistema cooperativo caficultor se han establecido agencias de compra de café con cubrimiento de todas las zonas productoras, creado almacenes de provisión agrícola y desarrollado proyectos de supermercados y centros de acopio. Lo más significativo de estas formas asociativas cooperativas es el suscitar una red de comercialización del grano, que es la base de la industria y que da la posibilidad a los caficultores de realizar la compra en lugares próximos a los centros de producción.

En cuanto a la relación establecida con la Federación Nacional de Cafeteros y teniendo como referente el hecho que muestra que el impulso del cooperativismo caficultor estuvo a cargo de la mencionada agremiación, desde una lógica inscrita en un interés por el reformismo agrario que buscó introducir en el campo la producción tecnificada, con miras a la exportación, es necesario mencionar que dicha institución representativa de la actividad en el orden nacional, se ha beneficiado a partir de su vinculación con las cooperativas. La Federación, al resolver sus principales tareas -la compra y la comercialización del café-, apoyada en las cooperativas, ha consolidado un movimiento cooperativo caficultor con acciones dirigidas a la comercialización del grano, el crédito, la venta de insumos agrícolas, la capacitación y educación de sus asociados, los programas sociales y de bienestar, lo mismo que la prestación de servicios y la modernización de sistemas de información y control. En este sentido, la relación o interacción entre la institucionalidad gremial y el cooperativismo ha significado una alianza exitosa.

Finalmente, la dinámica económica actual plantea diversos desafíos para los caficultores, los cuales pueden revolverse con el apoyo de las cooperativas, cuyo interés, sin desconocer su objetivo fundacional de trabajar por el mejoramiento de las condiciones de vida de los asociados y significar la esperanza de los miles de caficultores asociados, también es compatible con los propósitos del gremio que se identifican con los intereses de la Federación Nacional de Cafeteros, en términos de optimizar la rentabilidad y fortalecer su ejercicio económico.

\section{LISTA DE REFERENCIAS}

Arango, M. (2015). Medellin: violencia, lumpenización y economía barrial (1970-2015). Medellín: Fundación Universitaria María Cano.

Arias, F. (2015, abril 12). Cooperativas compraron $35 \%$ de la cosecha cafetera. El Colombiano. Recuperado de http://www.elcolombiano.com/negocios/ 
Bejarano, J. A. (1989). La economía colombiana entre 1946 y 1958. En J. Jaramillo Uribe, A. Tirado Mejía, J. A. Bejarano, y J. O. Melo (eds.), Nueva historia de Colombia (pp. 149-166). Bogotá: Planeta.

Cano, C., Vallejo, C., y Tique, E. (2012). El mercado mundial del café y su impacto en Colombia. Bogotá: Fondo Editorial Banco de la República. Recuperado de http://www.banrep.gov.co/

Colombia. Congreso de la República. (1927, noviembre 22). Ley 76. Sobre protección y defensa del café. Diario Oficial, núm. 20.650. Recuperado de https://www.redjurista.com/

Colombia. Congreso de la República (1998, agosto 4). Ley 454. Economía solidaria. Bogotá D. C. Recuperado de http://www.secretariasenado.gov.co/

Colombia. Superintendencia de Economía Solidaria. (2016). Entidades vigiladas que reportan información. Recuperado de http://www.supersolidaria.gov.co/

Cooperativa de Caficultores de Andes. (2010). Informe de gestión, 2010. Antioquia: Cooperativa de Caficultores de Andes.

Cooperativa de Caficultores de Andes. (2011). Informe de gestión, 2011. Colombia: Cooperativa de Caficultores de Andes.

Cooperativa de Caficultores de Andes. (2015a). Estatuto. Recuperado de https://www.cooperandes $. \mathrm{com} /$

Cooperativa de Caficultores de Andes. (2015b). Servicios. Recuperado de http://www.cooperandes $. \mathrm{com} /$

Cooperativa de Caficultores de Andes. (2018). Somos. https://www.cooperandes.com/

Federación Nacional de Cafeteros de Colombia. (2010). Economía institucional del café. Café de Colombia. Recuperado de http://www.cafedecolombia.com/

Federación Nacional de Cafeteros de Colombia. (2015). Comportamiento de la industria cafetera colombiana. Colombia: Federación Nacional de Cafeteros de Colombia. Recuperado de https://w ww.federaciondecafeteros.org/

García, R. G., y Olaya, E. S. (2006). Caracterización de las cadenas de valor y abastecimiento del sector agroindustrial del café. Cuadernos de Administración, 19(31), 197-217.

Jiménez, F. L. (2002). Cooperativismo: ayer, hoy y mañana. Medellín: Asociación Antioqueña de Cooperativas Confecoop.

Jiménez, F. L. (2007). Francisco Luis Jiménez Arcila Memorias 1980-2006. Medellín: Asociación Antioqueña de Cooperativas Confecoop.

Kaplinsky, R. (2004). Competitions policy and the global coffee and cocoa value chains. Conference for Trade and Development (pp. 1-31). Suiza: Naciones Unidas. Recuperado de http://hubrural.org/

Ocampo, J. A. (1994). Una breve historia cafetera de Colombia, 1830-1958. Bogotá: TM Editores.

Olivera, G. (2013). Cultura cooperativa y gestión empresarial en la cuenca lechera cordobesasantafesina. Argentina, fines del siglo xix a 1970. América Latina en la Historia Económica, 20(1), 199. DOI: $10.18232 /$ alhe.v20i1.512

Ospina, T. (1987). Industria y protección en Colombia 1810-1930. Medellín: Fundación Antioqueña para los Estudios Sociales.

Palacios, M. (1979). El café en Colombia, 1850-1970: una historia económica, social y política. Bogotá: Presencial Ltda./Fedesarrollo.

Parsons, J. J. (1997). La colonización antioqueña en el occidente de Colombia. Bogotá: Banco de la República/Ancora. 
Pérez, J. A. (2013). Economía cafetera y desarrollo económico en Colombia. Bogotá: Universidad Jorge Tadeo Lozano.

Arranca la cosecha en la 'tradicional' zona cafetera. (2015, agosto 25). Portafolio.com. Recuperado de https://www.portafolio.co/

Posada, J. I. (2009, agosto 2). La violencia y el café (I). Recuperado de https://www.elmundo.com/

Ramírez, R. (2008). Conflicto, mercado y condonación. Breve historia de paros y conflictos cafeteros en los años 90. En Y. A. Chicangana-Bayona, S. I. González y R. Ramírez (eds.), Historia trabajo, sociedad y cultura: ensayos interdisciplinarios (vol. 1, pp. 113-129). Medellín: Universidad Nacional de Colombia.

Vásquez, J. R. (1985). ¿Las cooperativas agrícolas en Antioquia, un fracaso? (Grado de Economista Agrícola). Universidad Nacional de Colombia, Colombia.

Zabala, H. (2016). Economía agraria y asociatividad cooperativa en Colombia. Recuperado de http://www.funlam.edu.co/

Zabala, H. y Arboleda, O. L. (2007). Francisco Luis Jiménez: sembrador de una esperanza, 1930-1960. Medellín: Fundación Universitaria Luis Amigó. 